\title{
Assessment of Ecosystem Service Value of the Liaohe Estuarine Wetland
}

\author{
Lifeng Li ${ }^{1}$, Fangli Su ${ }^{2,3}$, Mark T. Brown ${ }^{4}$, Haisheng Liu ${ }^{2,3, *}$ and Tieliang Wang ${ }^{2,3, *}$ \\ 1 College of Science, Shenyang Agricultural University, Shenyang 110866, China; xiyue_li@163.com \\ 2 College of Water Conservancy, Shenyang Agricultural University, Shenyang 110866, China; \\ sufangli8@163.com \\ 3 Liaoning Shuangtai Estuary Wetland Ecosystem Research Station, Nanjingzi Village, Dongguo Town, \\ Panshan County, Panjin Ctiy 124112, China \\ 4 Center for Environmental Policy, Environmental Engineering Sciences, University of Florida, Gainesville, \\ FL 32611, USA; mtb@ufl.edu \\ * Correspondence: liuhaisheng929@syau.edu.cn (H.L.); tieliangwang@126.com (T.W.); \\ Tel.: +86-24-8848-7134 (H.L.); + 86-24-8848-7009 (T.W.)
}

Received: 26 October 2018; Accepted: 4 December 2018; Published: 10 December 2018

check for updates

Featured Application: This research enhanced the significance of the intermediate-service value of a wetland system, which can draw the government or researchers to pay more attention to wetland management for the sustainability of wetland systems.

\begin{abstract}
The functions and services of wetland ecosystems to human society have been generally recognized. Currently, most evaluations of wetlands are a comprehensive evaluation of their ultimate value. It is rare to discuss for energy and matter lost and transferred. In this study, emergy theory was used to assess the ultimate and intermediate service values of the Liaohe estuarine wetland ecosystem. Results show that its ultimate service value was $\$ 28.2$ million, and its intermediate service value was $\$ 35,614.03$ million. The 1263 time difference between intermediate and ultimate value shows that much server value was dissipated in the form of energy. In the ultimate service value, the value of adjusting the atmosphere was $\$ 8.02$ million, accounting for $28.45 \%$ of the total value, and flood diversion and storage value was $\$ 6.98$ million, accounting for $24.75 \%$. These results illustrate that the most important service value of the Liaohe estuarine wetland ecosystem is to adjust the atmosphere and divert and store floods. In intermediate service value, maintaining-biodiversity value was $\$ 34,182$ million, accounting for $95.98 \%$ of total value, showing that the Liaohe estuarine wetland plays an important role in species resources and regional seed banks.
\end{abstract}

Keywords: Liaohe estuarine wetlands; ultimate service value; intermediate service value; emergy theory

\section{Introduction}

Wetland ecosystems are known as the kidneys of Earth [1] and provide a variety of services to humanity. Understanding these services and their "value" to humans can provide necessary information for resource managers and policy makers to make informed decisions. Understanding and evaluating wetland services needs a system approach that considers all variables influencing and driving the system [2]. In addition, as services are extracted, and ecosystems are used by humans, the flows of ecosystem services may change, thus introducing a dynamic aspect that also needs to be considered.

In the last decade or so, the issue of computing the value of ecosystem services has become an important area of research based on the service function of the ecosystem. Its service functions can be 
divided into gas, waste management, climate regulation, signal adjustment, water adjustment and supply, erosion control and stop sand, soil formation, nutrient cycling, pollination, biological control, shelter, food production, raw materials, genetic resources, leisure, culture, and other types, according to the different scales of ecological systems and the purpose of the research [3]. Its server function is also divided into a regulating, habitat, production, and information functions [4]. For another classification system of wetland ecosystems (the millennium ecosystem assessment-MA), there are four types: cultural services, supply services, regulating services, and support services [5].

Service value provided by a wetland ecosystem has received increasing attention for human survival, and the method to assess this service value is improving. Sutton calculated the global ecosystem service value based on GPS satellite images [6]. Fan provided and used the water-footprint method to describe the ecological environment and social economy of water resources according to the ecological-footprint method [7]. Jenkins et al. evaluated the service value of alleviating greenhouse-gas emissions, nitrogen release, and entertainment for the Mississippi River wetland [8]. Grossmann used the travel-cost method to assess the entertainment value of the Spreewald wetland [9]. Lannas and Turpie compared the supply values of two wetlands in southern Africa through informal interviews and a structured household survey [10]. Zhang and Lu evaluated the ecosystem service value of the Zoige alpine wetland using a multicriteria evaluation method [11]. Nelson evaluated regional ecosystem servics value of the Willamette valley in Oregon based on the INVEST model [12], which can better reflect the interaction between an ecological system and the surrounding environment [13].

All of the above studies are the comprehensive evaluation of wetland values, and the monetary value of wetland was also calculated, which proved the huge value of wetlands. However, the fact that has been ignored in these studies is that the service value of wetlands always changes with the variations of wetland ecosystems. That means the process and results of wetland services have not been considered, leading to repeated calculations and influencing assessment accuracy. Most researchers have tried to resolve this problem. Boyd divided ecosystem services into intermediate process, service, and benefit based on the perspective of environmental accounting [14]. Fisher, however, thought that service is different from benefit [15]. Barnard et al. divided the ecosystem service into core ecosystem processes, ecosystem processes producing benefit, and benefiting ecosystem services based on Fisher's research [16]. Li divided ecosystem services into ultimate and intermediate services, and considered the ultimate service value as the total value of wetland ecosystem services [17], which can avoid the repeat computation of intermediate value. Even so, there is still lack of attention on the dynamic change of wetland ecosystem value, especially for the value of intermediate service processes. This study aims to separately calculate the ultimate service value and intermediate service value of the Liaohe estuarine wetland due to their different content, which can avoid the repeat calculation of wetland service value, paying particular attention to the impact of changes in service provision, and improving the assessment theory of wetland value.

In addition, the scientific and practical effectiveness of the assessment results using the method of pure economic value evaluation is questionable due to publicity, externality, and the difficulty in monetizing wetland-ecosystem service value. For the current popular market-price method, it is difficult to reflect consumer surplus, which can lead to imprecise results of unit value and ultimate-value evaluation. Emergy theory, proposed by Odum [18] in the 1990s, can effectively solve the above problems, because the energy flow and value flow are comprehensively considered in this theory. This theory has been very popular in ecosystem evaluation since its beginning. Campbell et al. accounted for the natural capital and ecosystem of the national forest system of the United States based on emergy theory [19]. Lu et al. calculated the ecosystem service value of the subtropics forest in southeastern China [20]. Therefore, emergy theory was adopted to evaluate the service value of the Liaohe estuarine wetland.

The Liaohe estuarine wetland is located downstream of Liaohe River, one of China's seven major rivers. It is on the path of eight migratory routes for migratory birds around the world, and can covertly provide the largest habitat for endangered species. This wetland is also the southernmost 
global area for leopard seal and red-crowned-crane reproduction. Therefore, it becomes an important transit point and destination for East Asia-Australia migratory birds. In this wetland, reed wetland is irrigated and harvested by mainly artificial covers, and Suaeda heteroptera with regional characteristic form a vermelha landscape, creating one of the most famous and representative regions of biodiversity conservation in the world. In this study, the emergy method was adopted to evaluate the intermediate and ultimate ecosystem service values of the Liaohe estuarine wetland, drawing more attention to the service process of the wetland system and providing the theoretical basis for the protection and rational utilization of Liaohe estuarine wetland resources.

\section{Materials and Methods}

\subsection{Study Site}

The Liaohe estuarine wetland is located in Panjin City, Liaoning Province, China, the southernmost tip of the Liaohe delta, covering the range of $121^{\circ} 30^{\prime} \sim 122^{\circ} 00^{\prime} \mathrm{E}, 40^{\circ} 41^{\prime} \sim 41^{\circ} 10^{\prime} \mathrm{N}$, with a total area of about $577.69 \mathrm{~km}^{2}$ and a coastline of $118 \mathrm{~km}$. It is the largest wetland nature reserve in China (Figure 1). It is mainly composed of reed marshes, intertidal mudflats, and waters. In this wetland, animal resources are mainly the wild-animal population of migratory waterfowl. In recent years, this wetland has suffered different degrees of destruction due to oil exploration, tourism development, and population growth.

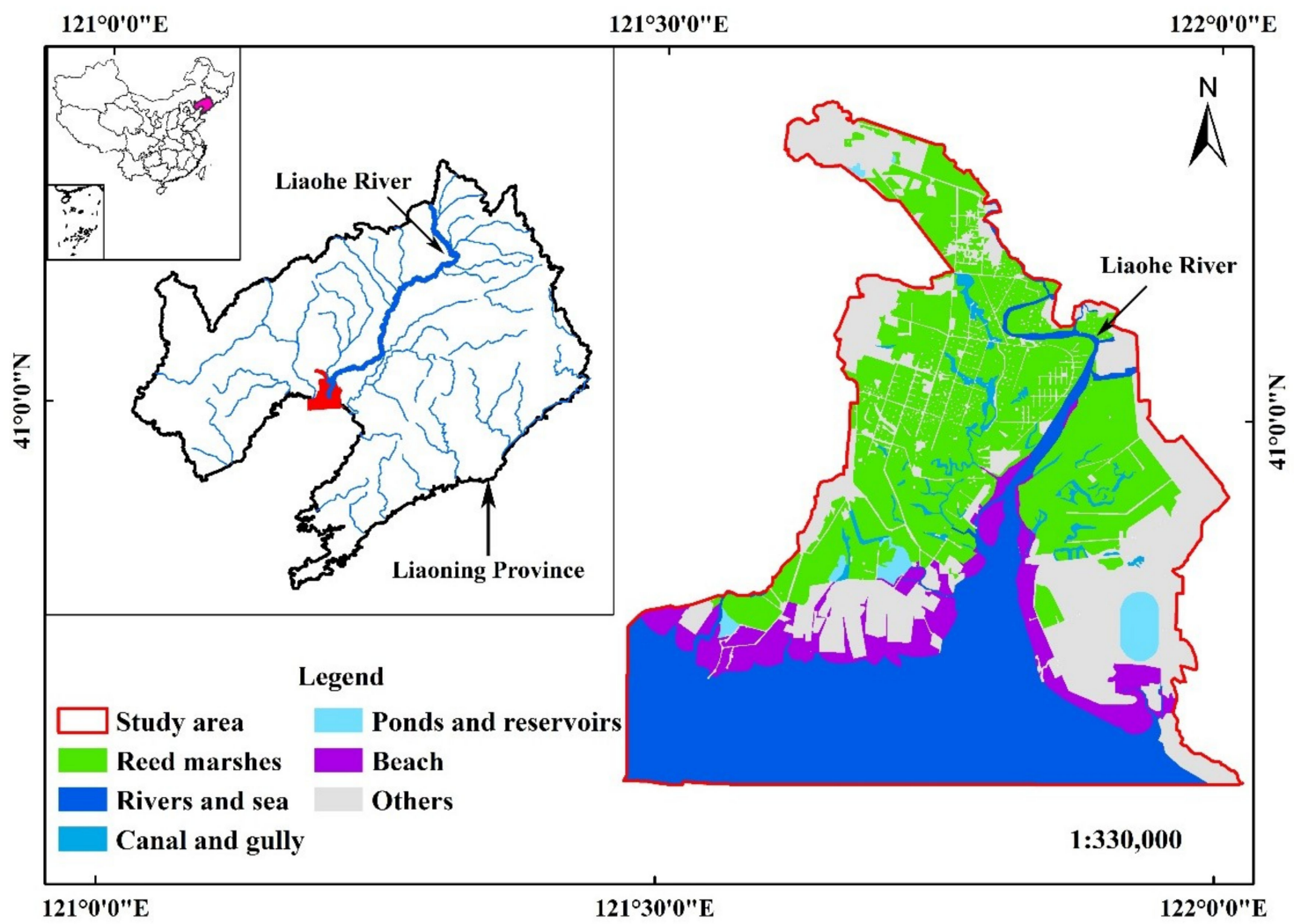

Figure 1. Location of the Liaohe estuarine wetland.

The Liaohe estuarine wetland belongs to the northern temperate zone continental semihumid monsoon climate, with four distinctive seasons, including a hot rainy season. Mean annual temperature is $8.4^{\circ} \mathrm{C}$, and mean annual rainfall is $625.6 \mathrm{~mm}$. Rainfall is mainly concentrated in the summer, making up for $63 \%$ of total annual precipitation. Rainfall in winter is minimal, making up for $2.2 \%$ of total annual precipitation. Mean annual evaporation is greater than mean annual precipitation. Annual average evaporation is $1548 \mathrm{~mm}, 2.5$ times the annual rainfall. 


\subsection{Methods}

\subsubsection{Emergy-Analysis Method}

Emergy can be defined as the available energy (exergy) of one form used up directly and indirectly to produce a service or product; its units are solar-emergy joules (sej) [18]. This conception can measure and compare the actual energy values in different forms and hierarchies by using the unified standard. Its calculation method is that flows of energy, materials, or services in a system are transformed into the common unit of solar emergy by multiplying units of energy or mass by the corresponding unit emergy values (UEV). UEV is defined as the form of available energy (usually solar) that is required to produce a unit of another form of energy [18]. If the produced units are in joules of available energy, then the UEVs are called transformity. If the produced units are expressed in mass, the UEVs are called specific emergy. The units of each are as follows: transformity $=\mathrm{sej} / \mathrm{J}$, and specific emergy $=\mathrm{sej} / \mathrm{g}$. A third type of UEV is emergy per unit of currency, such as dollars, in which case, units are sej/\$.

In practice, UEVs are computed from real processes that have been in operation for a sufficient amount of time that makes them likely to be operating at close-to-optimal performance. Ideally, UEVs are computed for each analysis; however, time and resource constraints make this ideal difficult to achieve. Instead, most emergy analyses rely on UEVs computed by others. Odum, Brown, Tillery, and Bastianoniet have computed UEVs for a variety of products and services [18,21-23]. Two databases, the National Environmental Accounting Database and the Emergy Data Base, provide comprehensive lists of UEVs previously computed by others [24,25]. UEVs used in this study were obtained from these sources.

\subsubsection{System Diagram}

Not only are there the material and energy flows in the Liaohe estuarine wetland ecosystem, but also the social economic monetary and information flows. In order to describe the flowing energy process and make the emergy-calculation process of a wetland ecosystem convenient, the flowchart of the wetland ecosystem was drawn based on the design of the Odum energy language [26], shown in Table 1. This chart reflects the whole process of energy input and output. For the Liaohe estuarine wetland, the system energy-flow diagram, including the relationship between ecological-system components as well as that of the system energy, is shown in Figure 2. This figure was drawn based on determining the energy sources of the Liaohe estuarine wetland ecosystem and its components.

Table 1. Symbol explanations of an emergy system.

System frame: A rectangular box drawn to represent the boundaries of the selected
system.


Table 1. Cont.

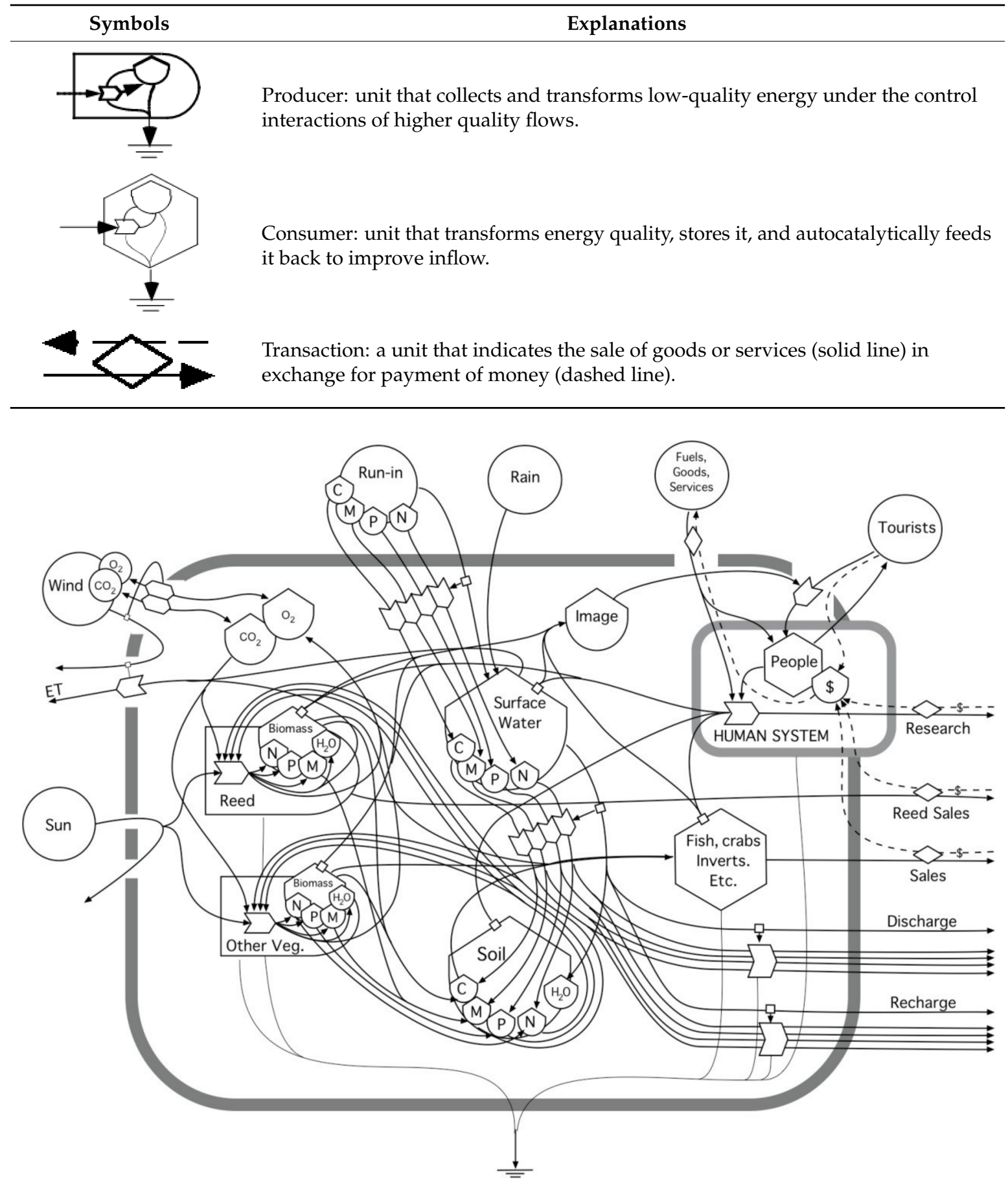

Figure 2. System diagram of the Liaohe estuarine wetland system.

\subsubsection{Calculation Method of Wetland-Ecosystem Value}

The assessment of wetland ecosystem service value should be performed from maintaining the normal system operation and providing service and impact on the surrounding environment. Based on this, we classified wetland ecosystem service values as either ultimate service value or intermediate service value. Ultimate service value refers to a service being directly used for well-being. Intermediate service value is to keep the ecosystem itself running, and it is continuously converting into ultimate service value. This service value cannot be directly used by humans, but it is part of the necessary conditions for converting it into ultimate service value. In Figure 2, the outflows of material production, 
flood diversion, and storage, water-quality purification, gas and soil regulation, leisure entertainment, and scientific research and education were classified as ultimate service values. The inside flows of supplementing groundwater, water conservation, and nutrient recycling, and maintaining biodiversity in a system are part of the intermediate service values, based on existing results and studies on the Liao estuarine wetland [14-17].

\section{Ultimate Service Value}

\section{(1) Material Production Value}

The material-production value of the Liaohe estuarine wetland mainly includes the plant-resource value and the value of aquatic products. The key plant resource in this wetland is mainly reed, occupying the majority of the wetland's plant species. Reed yield and aquatic-product output can be obtained from the local yearbook.

\section{(2) Flood Diversion and Storage Value}

The storage capacity of this wetland and the reservoir, and the annual average runoff in this wetland were used to calculate the total storage capacity of the Liaohe estuarine wetland. This information was from the local yearbook from 2006 to 2015 . The calculated total storage capacity was the value of flood diversion and storage of the Liaohe estuarine wetland.

\section{(3) Water-Quality Purification Value}

There is a large number of paper mills upstream of the Liaohe estuarine wetland. The value of water-quality purification is the purification capacity of this wetland for paper-making wastewater. The content difference of nitrogen, phosphorus, and heavy-metal ions between upstream and downstream of this wetland was used to indicate purification capacity. Our experimental results from 2006 to 2015 can support the evaluation of water-quality purification.

\section{(4) Gas-Regulation Value}

Gas regulation of the wetland ecosystem is the amount of carbon dioxide $\left(\mathrm{CO}_{2}\right)$ that can be aborted and stored, and of oxygen $\left(\mathrm{O}_{2}\right)$ that can be released, regulating the components of atmosphere and controlling global warming. This value was calculated by using the area of the wetland and the reed yield.

\section{(5) Soil-Conservation Value}

Soil conservation of the Liaohe estuarine wetland is the runoff energy that can be consumed by the wetland ecosystem, and the sand carried by the runoff that can be stored in the soil reservoir by turning into a form of emergy. Soil-reservoir emergy was used to calculate the emergy of organic carbon, total nitrogen (TN), and total phosphorus (TP).

\section{(6) Leisure-Entertainment Value}

The leisure entertainment of the Liaohe estuarine wetland is ecological tourism activities, such as fishing and bird- watching, which can be implemented. The emergy of tourism activities is from the chorography of Panjin. Tourism revenues from 2013 to 2015 were used.

\section{(7) Scientific Research and Education Value}

The value of scientific research and education was calculated by using the number of scientific-research publications. Based on the results of Meillaud [27], the average number of annual papers published in the last three years was considered as the newest research achievement. In this study, papers with Liao estuarine wetland and Panjin wetland keywords were searched in the database of Chinese periodical literature from 2013 to 2015, and the number of published papers was counted. 
Intermediate Service Value

(1) Groundwater Supplementation Value

In the process of determining the value of supplementing groundwater, only the value supplemented by reed wetland to the groundwater was considered. River infiltration, canal-system leakage, irrigation-water leakage, and underground lateral runoff were not calculated. In this wetland, the reed is submerged by water for six months, from May to October each year. When the infiltration amount of surface water into the groundwater was calculated, the surface-water infiltration coefficient was determined by the reed-wetland infiltration coefficient [27], determining groundwater emergy.

\section{(2) Water-Conservation Value}

The value of water conservation was determined by measuring the rainfall intercepted by reeds aboveground and calculating the reed area of the Liaohe estuarine wetland based on the method of water conservation of forest ecological systems. The rainfall intercepted by reeds aboveground was obtained from a field survey.

(3) Nutrient-Recycling Value

There are two methods of determining the value of nutrient recycling: maintaining nutrients in the bio bank, and maintaining nutrients in the soil reservoir. This method aims to determine the ratio between net primary productivity and the amount of nutrients. In this study, the method of maintaining nutrients in the bio bank was adopted. $\mathrm{N} / \mathrm{P}$ content in the net primary productivity of reeds was used to calculate the value of nutrient recycling.

\section{(4) Biodiversity Value}

At present, there are 253 species of birds living in the Liaohe estuarine wetland. The value of providing the habitat of this island for birds was used to evaluate the biodiversity value because maintaining bird-population quantity and quality, especially endangered birds, is the most important value of the Liaohe estuarine wetland.

From the above, the total amount of ecosystem services (g) was converted into energy $(\mathrm{J})$, then converted into emergy through emergy transformity (sej/J or sej/g) to calculate each emergy of all wetland server values. Finally, emergy was converted into monetary value through the emergy currency-conversion rate. In this study, the related published survey reports and papers were referred [27-30], and the indices of all emergy referred to the research results by Liu [31]. The emergy currency -onversion rate was $1.21 \times 10^{13} \mathrm{sej} / \$[32]$.

\subsubsection{Data Sources}

The data involved in the evaluation process were mainly from a field survey, sampling, and experimental analysis from 2011 to 2015. The basic information was from the Panjin statistical yearbook and field investigations in 2015.

\section{Results}

\subsection{Ecosystem Service Value of the Liaohe Estuarine Wetland}

\subsubsection{Ultimate Service Value}

Material-Production Value

The reed yield in this wetland was 150 million $\mathrm{kg}$ in 2015. Aquatic products mainly include crabs, shrimp, freshwater fish, and sea cucumbers. Their productions were 1 million, 250,000, 50,000, and 2.5 million $\mathrm{kg}$, respectively. 
Flood Diversion and Storage Value

The average storage capacity of this wetland and reservoir was 1481 million $\mathrm{m}^{3}$ from 2006 to 2015, and mean annual runoff was 1000 million $\mathrm{m}^{3}$ from 2006 to 2015 , so the total storage capacity of the Liaohe estuarine wetland was 2481 million $\mathrm{m}^{3}$ from 2006 to 2015.

Water-Quality Purification Value

The average contents of nitrogen and phosphorus absorbed by the reed in the Liaohe estuarine wetland were 1535.76 and $785.87 \mathrm{mg} \cdot \mathrm{m}^{-2} \cdot \mathrm{a}^{-1}$, respectively, from 2006 to 2015 . The content of heavy-metal ions ( $\mathrm{M}$ included $\mathrm{Cu}^{2+}, \mathrm{Zn}^{2+}, \mathrm{Pb}^{2+}$ and $\mathrm{Cd}^{2+}$, shown in Figure 2) were 7.90, 14.65, 17.22 , and $0.76 \mathrm{mg} \cdot \mathrm{m}^{-2} \cdot \mathrm{a}^{-1}$ from 2006 to 2015 , respectively.

Gas-Regulation Value

The average reed yield was $1.5 \times 10^{11} \mathrm{~g}$, the content of absorbed $\mathrm{CO}_{2}$ in this wetland was $2.23 \times 10^{11} \mathrm{~g}$, and the released $\mathrm{O}_{2}$ content was $1.71 \times 10^{11} \mathrm{~g}$.

\section{Soil-Conservation Value}

The area of the Liaohe estuarine wetland was $577.69 \mathrm{~km}^{2}$, the average product of reed was $473.12 \mathrm{~g} / \mathrm{m}^{2}$, and the total nitrogen and phosphorus fixed was $1.84 \times 10^{8} \mathrm{~g}$, organic carbon was $2.59 \times 10^{8} \mathrm{~g}$.

Leisure-Entertainment Value

The annual average income was $\$ 2.63 \times 10^{6}$ from 2013 to 2015 based on local chronicles.

Scientific Research and Education Value

The total papers searched for from 2013 to 2015 were 65, and the average number of published papers was 22. The average number of pages of each paper was 6 , and the total number of paper pages was 132 each year.

\subsubsection{Intermediate Service Value}

Groundwater Supplementation Value

The area of the Liaohe estuarine wetland is $547.69 \mathrm{~km}^{2}$, the period of the wetland covered with water was six months each year, the soil-infiltration coefficient of the Liaohe estuarine wetland was $2.01 \times 10^{-6} \mathrm{~m} / \mathrm{s}$, and the supplemented groundwater was $1.84 \times 10^{10} \mathrm{~m}^{3}$.

\section{Water-Conservation Value}

The water-holding capacity of vegetation was $1389 \mathrm{~g} / \mathrm{m}^{2}$ by field experiment, the area of the Liaohe estuarine wetland was $577.69 \times 10^{6} \mathrm{~m}^{2}$, the areas covered by reeds occupied $97.5 \%$, and the annual volume of water conservation was $4.43 \times 10^{8} \mathrm{~m}^{3}$.

Nutrient-Recycling Value

Reed biomass was $1.50 \times 10^{11} \mathrm{~g}$ each year, and the average contents of TN and TP were $3.245 \mathrm{mg} / \mathrm{kg}$ and $1.66 \mathrm{~g} / \mathrm{kg}$, respectively. The total weight of absorbed TN was $4.87 \times 10^{8} \mathrm{~g}$, and TP was $2.49 \times 10^{8} \mathrm{~g}$.

\section{Biodiversity Value}

There are 253 species of birds in this wetland according to the statistical yearbook of the Liaohe estuarine wetland, including eight species of national first-level protected animals. In this study, the value of protecting birds was calculated by using eight species of national first-level protected 
birds, and the value of protecting normal birds by using 100,000, the sum of two values that are the biodiversity value of the Liaohe estuarine wetland.

Table 2 shows that there are $1.538 \times 10^{11} \mathrm{~g}$ of material resources produced by the Liaohe estuarine wetland each year, creating a value of $\$ 2.68$ million. The regulated surface runoff was $2.48 \times 10^{10} \mathrm{~m}^{3}$, playing the role of flood diversion and storage and creating a value of $\$ 6.98$ million. The total weight of nitrogen, phosphorus, and heavy metals was $7.49 \times 10^{8} \mathrm{~g}$, purifying the water and creating a value of $\$ 1.05$ million. This wetland absorbed $2.34 \times 10^{11} \mathrm{~g}$ of $\mathrm{CO}_{2}$ and released $1.71 \times 10^{11} \mathrm{~g}$ of $\mathrm{O}_{2}$, playing a role in purifying air and acting as a carbon sink, creating value of $\$ 8.02$ million. Tourism income in this wetland was $\$ 2.63$ million, and the value of scientific research and education was $\$ 3.70$ million. In addition, this wetland provided habitat for 253 bird species, maintaining biodiversity and creating value of $\$ 34181.82$ million. It also supplemented $1.01 \times 10^{10} \mathrm{~m}^{3}$ of groundwater, creating a value of $\$ 1431.63$ million. Water conservancy of $4.4 \times 10^{11} \mathrm{~m}^{3}$ in this wetland created a value of $\$ 0.03$ million. The plants of this wetland absorbed $7.36 \times 10^{5} \mathrm{~kg}$ of N and P, creating $\$ 0.55$ million.

Table 2. Emergy evaluation of the Liaohe estuarine wetland ecosystem.

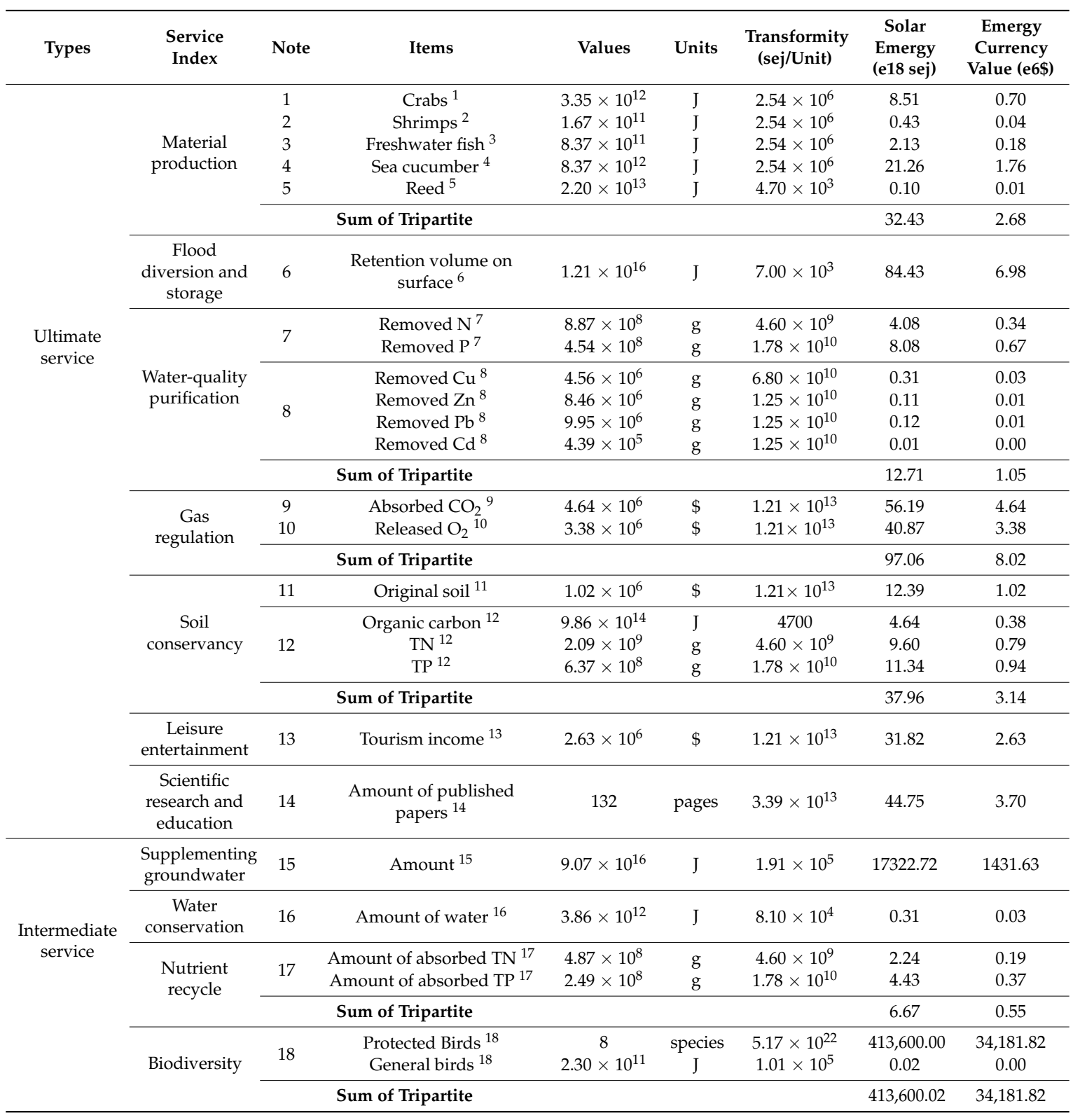


Table 2. Cont

\begin{tabular}{|c|c|c|c|c|}
\hline \multirow{9}{*}{1} & Crabs & & & \\
\hline & products $=$ & $1.00 \times 10^{9}$ & g/year & Yearbook (2015) \\
\hline & proportion of dry weight $=$ & 20 & $\%$ & \\
\hline & standard calorific of carbon $=$ & 4 & $\mathrm{kcal} / \mathrm{g}$ & \\
\hline & conversion coefficient $=$ & 4186 & $\mathrm{~J} / \mathrm{kcal}$ & \\
\hline & Energy $(J)=$ & (produces) $^{*}$ & of dry we & conversion calfficient) \\
\hline & Energy $(\mathrm{J})=$ & $\left(1 \times 10^{9} \mathrm{~g} /\right.$ & g) $(4187 \mathrm{~J} /$ & \\
\hline & $=$ & $3.35 \times 10^{12}$ & $\mathrm{~J}$ & \\
\hline & $\mathrm{UEV}=$ & $2.54 \times 10^{6}$ & sej/J & Odum [18] \\
\hline \multirow{9}{*}{2} & Shrimps & & & \\
\hline & products $=$ & $5.00 \times 10^{7}$ & $\mathrm{~g} /$ year & Yearbook (2015) \\
\hline & proportion of dry weight $=$ & 20 & $\%$ & \\
\hline & standard calorific of carbon $=$ & 4 & $\mathrm{kcal} / \mathrm{g}$ & \\
\hline & conversion coefficient $=$ & 4186 & $\mathrm{~J} / \mathrm{kcal}$ & \\
\hline & Energy $(J)=$ & (produces) $^{*}$ & of dry we & conversion calfficient) \\
\hline & Energy $(\mathrm{J})=$ & $\left(1 \times 10^{9} \mathrm{~g} /\right.$ & g) $(4187 \mathrm{~J} /$ & \\
\hline & $=$ & $1.67 \times 10^{11}$ & $\mathrm{~J}$ & \\
\hline & $\mathrm{UEV}=$ & $2.54 \times 10^{6}$ & sej/J & Odum [18] \\
\hline \multirow{9}{*}{3} & Freshwater fish & & & \\
\hline & products $=$ & $2.50 \times 10^{8}$ & $\mathrm{~g} /$ year & Yearbook (2015) \\
\hline & proportion of dry weight $=$ & 20 & $\%$ & \\
\hline & standard calorific of carbon $=$ & 4 & $\mathrm{kcal} / \mathrm{g}$ & \\
\hline & conversion coefficient $=$ & 4186 & $\mathrm{~J} / \mathrm{kcal}$ & \\
\hline & Energy $(\mathrm{J})=$ & (produces) $^{*}$ & of dry we & conversion calfficient) \\
\hline & Energy $(\mathrm{J})=$ & $\left(1 \times 10^{9} \mathrm{~g} /\right.$ & g) $(4187 \mathrm{~J} /$ & \\
\hline & $=$ & $8.37 \times 10^{11}$ & $\mathrm{~J}$ & \\
\hline & $\mathrm{UEV}=$ & $2.54 \times 10^{6}$ & sej/J & Odum [18] \\
\hline \multirow{9}{*}{4} & Sea cucumber & & & \\
\hline & products $=$ & $2.50 \times 10^{9}$ & $\mathrm{~g} /$ year & Yearbook (2015) \\
\hline & proportion of dry weight $=$ & 20 & $\%$ & \\
\hline & standard calorific of carbon $=$ & 4 & $\mathrm{kcal} / \mathrm{g}$ & \\
\hline & conversion coefficient $=$ & 4186 & $\mathrm{~J} / \mathrm{kcal}$ & \\
\hline & Energy $(J)=$ & (produces) $)^{*}$ & of dry we & conversion calfficient) \\
\hline & Energy $(J)=$ & $\left(1 \times 10^{9} \mathrm{~g} /\right.$ & g) $(4187 \mathrm{~J} /$ & \\
\hline & $=$ & $8.37 \times 10^{12}$ & $\mathrm{~J}$ & \\
\hline & $\mathrm{UEV}=$ & $2.54 \times 10^{6}$ & sej/J & Odum [18] \\
\hline \multirow{9}{*}{5} & Reed & & & \\
\hline & Reed Prod = & $1.50 \times 10^{11}$ & $\mathrm{~g} /$ year & Yearbook (2015) \\
\hline & content of carbon = & 0.437 & $\%$ & \\
\hline & carbon calorific value $=$ & 8 & $\mathrm{kcal} / \mathrm{g}$ & \\
\hline & conversion coefficient $=$ & 4186 & $\mathrm{~J} / \mathrm{kcal}$ & \\
\hline & Energy $(J)=$ & (reed prod) & carbon $)^{*}(\mathrm{c}$ & version calfficient) \\
\hline & Energy $(J)=$ & $\left(1 \times 10^{9} \mathrm{~g} /\right.$ & g) $(4187 \mathrm{~J} /$ & \\
\hline & $=$ & $2.20 \times 10^{13}$ & $\mathrm{~J}$ & \\
\hline & $\mathrm{UEV}=$ & $4.70 \times 10^{3}$ & sej/J & Odum [18] \\
\hline
\end{tabular}


Table 2. Cont.

\begin{tabular}{|c|c|c|c|c|}
\hline \multirow{8}{*}{6} & \multicolumn{4}{|c|}{ Retention volume on surface } \\
\hline & Volume $=$ & $2.48 \times 10^{9}$ & $\mathrm{~m}^{3} /$ year & Yearbook 2006-2015 \\
\hline & rain density $=$ & $1.03 \times 10^{3}$ & $\mathrm{~kg} / \mathrm{m}^{3}$ & \\
\hline & gibbs energy $=$ & 4720 & $\mathrm{~J} / \mathrm{kg}$ & \\
\hline & Energy $(J)=$ & (volume)*(water & y)*(gibbs energy) & \\
\hline & Energy $(\mathrm{J})=$ & $\left(1.481 \times 10^{9} \mathrm{~m}^{3}\right)^{*}$ & $\left.10^{3} \mathrm{~kg} / \mathrm{m}^{3}\right)^{*}(4720 \mathrm{~J} / \mathrm{kg})$ & \\
\hline & $=$ & $1.21 \times 10^{16}$ & $\mathrm{~J} /$ year & \\
\hline & $\mathrm{UEV}=$ & 7000 & sej/J & Vilbiss et al. [33] \\
\hline \multirow{13}{*}{7} & Removed N/P & & & \\
\hline & Area $=$ & $5.78 \times 10^{8}$ & $\mathrm{~m}^{2}$ & Yearbook (2015) \\
\hline & Absorb unit area of $\mathrm{N}=$ & 1535.76 & $\mathrm{mg} /\left(\mathrm{m}^{2} /\right.$ year $)$ & Measured \\
\hline & Energy $(\mathrm{g})=$ & $(\text { Area })^{*}$ (Absorb u & a of N) & \\
\hline & Energy $(\mathrm{g})=$ & $\left(5.78 \times 10^{8} \mathrm{~m}^{2}\right)^{*}($ & $\left.6 \mathrm{mg} / \mathrm{m}^{2 *} \mathrm{yr}\right) /(1000 \mathrm{mg} / \mathrm{g})$ & \\
\hline & $=$ & $8.87 \times 10^{8}$ & g/year & \\
\hline & $\mathrm{UEV}=$ & $4.60 \times 10^{9}$ & $\mathrm{sej} / \mathrm{g}$ & Odum [18] \\
\hline & Area $=$ & $5.78 \times 10^{8}$ & $\mathrm{~m}^{2}$ & Yearbook (2015) \\
\hline & Absorb unit area of $\mathrm{P}=$ & 785.87 & $\mathrm{mg} /\left(\mathrm{m}^{2} /\right.$ year $)$ & Measured \\
\hline & Energy $(\mathrm{g})=$ & $(\text { Area })^{*}($ Absorb u & a of $P$ ) & \\
\hline & Energy $(\mathrm{g})=$ & $\left(5.78 \times 10^{8} \mathrm{~m}^{2}\right)^{*}($ & $\left.\mathrm{mg} / \mathrm{m}^{2 *} \mathrm{yr}\right) /(1000 \mathrm{mg} / \mathrm{g})$ & \\
\hline & $=$ & $4.54 \times 10^{8}$ & $\mathrm{~g} /$ year & \\
\hline & $\mathrm{UEV}=$ & $1.78 \times 10^{10}$ & $\mathrm{sej} / \mathrm{g}$ & Odum [18] \\
\hline \multirow{25}{*}{8} & & Removed Heavy I & & \\
\hline & Area $=$ & $5.78 \times 10^{8}$ & $\mathrm{~m} 2$ & Yearbook (2015) \\
\hline & Absorb unit area of $\mathrm{Cu}=$ & 7.9 & $\mathrm{mg} /\left(\mathrm{m}^{2} /\right.$ year $)$ & Measured \\
\hline & Energy $(\mathrm{g})=$ & $(\text { Area })^{*}($ Absorb u & $\mathrm{a}$ of $\mathrm{Cu}$ ) & \\
\hline & Energy $(\mathrm{g})=$ & $\left(5.78 \times 10^{8} \mathrm{~m}^{2}\right)^{*}($ & $\left.\mathrm{ng} / \mathrm{m}^{2 *} \mathrm{yr}\right) /(1000 \mathrm{mg} / \mathrm{g})$ & \\
\hline & $=$ & $4.56 \times 10^{6}$ & g/year & \\
\hline & $\mathrm{UEV}=$ & $6.80 \times 10^{10}$ & $\mathrm{sej} / \mathrm{g}$ & Liu [31] \\
\hline & Area $=$ & $5.78 \times 10^{8}$ & $\mathrm{~m}^{2}$ & Yearbook (2015) \\
\hline & Absorb unit area of $\mathrm{Zn}=$ & 14.65 & $\mathrm{mg} /\left(\mathrm{m}^{2} /\right.$ year $)$ & Measured \\
\hline & Energy $(\mathrm{g})=$ & $(\text { Area })^{*}($ Absorb u & a of $\mathrm{Zn})$ & \\
\hline & Energy $(\mathrm{g})=$ & $\left(5.78 \times 10^{8} \mathrm{~m}^{2}\right)^{*}(1$ & $\left.\mathrm{mg} / \mathrm{m}^{2 *} \mathrm{yr}\right) /(1000 \mathrm{mg} / \mathrm{g})$ & \\
\hline & $=$ & $8.46 \times 10^{6}$ & g/year & \\
\hline & $\mathrm{UEV}=$ & $1.25 \times 10^{10}$ & $\mathrm{sej} / \mathrm{g}$ & Liu [31] \\
\hline & Area $=$ & $5.78 \times 10^{8}$ & $\mathrm{~m}^{2}$ & Yearbook (2015) \\
\hline & Absorb unit area of $\mathrm{Pb}=$ & 17.22 & $\mathrm{mg} /\left(\mathrm{m}^{2} /\right.$ year $)$ & Measured \\
\hline & Energy $(\mathrm{g})=$ & $(\text { Area })^{*}$ (Absorb u & a of $\mathrm{Pb}$ ) & \\
\hline & Energy $(\mathrm{g})=$ & $\left(5.78 \times 10^{8} \mathrm{~m}^{2}\right)^{*}($ & $\left.\mathrm{ng} / \mathrm{m}^{2 *} \mathrm{yr}\right) /(1000 \mathrm{mg} / \mathrm{g})$ & \\
\hline & $=$ & $9.95 \times 10^{6}$ & g/year & \\
\hline & $\mathrm{UEV}=$ & $1.25 \times 10^{10}$ & $\mathrm{sej} / \mathrm{g}$ & Liu [31] \\
\hline & Area $=$ & $5.78 \times 10^{8}$ & $\mathrm{~m}^{2}$ & Yearbook (2015) \\
\hline & Absorb unit area of $\mathrm{Cd}=$ & 0.76 & $\mathrm{mg} /\left(\mathrm{m}^{2} /\right.$ year $)$ & Measured \\
\hline & Energy $(\mathrm{g})=$ & $(\text { Area })^{*}($ Absorb u & a of $\mathrm{Cd}$ ) & \\
\hline & Energy $(\mathrm{g})=$ & $\left(5.78 \times 10^{8} \mathrm{~m}^{2}\right)^{*}($ & $\left.\mathrm{ng} / \mathrm{m}^{2 *} \mathrm{yr}\right) /(1000 \mathrm{mg} / \mathrm{g})$ & \\
\hline & $=$ & $4.39 \times 10^{5}$ & $\mathrm{~g} /$ year & \\
\hline & $\mathrm{UEV}=$ & $1.25 \times 10^{10}$ & $\mathrm{sej} / \mathrm{g}$ & Liu [31] \\
\hline
\end{tabular}


Table 2. Cont

\begin{tabular}{|c|c|c|c|c|}
\hline \multirow{8}{*}{9} & absorbed $\mathrm{CO}_{2}$ & & & \\
\hline & Reed Prod $=$ & $1.50 \times 10^{11}$ & g/year & Yearbook (2015) \\
\hline & $\begin{array}{r}\text { transfermation coefficient } \\
\text { from } \mathrm{CO}_{2} \text { to the net primary } \\
\text { productivity }=\end{array}$ & 0.641 & & \\
\hline & $\mathrm{PCO}_{2}=$ & $4.83 \times 10^{-5}$ & $\$ / g$ & \\
\hline & Energy $(\$)=$ & $(\text { reed prod })^{*}(\operatorname{tran}$ & tion coeffic & \\
\hline & Energy $(\$)=$ & $\left(1.50 \times 10^{11} \mathrm{~g}\right)^{*}(0$ & $4.83 \times 10^{-}$ & \\
\hline & $=$ & $4.64 \times 10^{6}$ & $\$$ & \\
\hline & UEV $=$ & $1.21 \times 10^{13}$ & sej/\$ & King [32] \\
\hline \multirow{10}{*}{10} & Released $\mathrm{O}_{2}$ & & & \\
\hline & Reed Prod $=$ & $1.50 \times 10^{11}$ & g/year & Yearbook (2015) \\
\hline & $\begin{array}{r}\text { transfermation coefficient } \\
\text { from } \mathrm{CO}_{2} \text { to the net primary } \\
\text { productivity }=\end{array}$ & 0.641 & & \\
\hline & Molecular weight of $\mathrm{O}_{2}=$ & 32 & & \\
\hline & Molecular weight of $\mathrm{CO}_{2}=$ & 44 & & \\
\hline & $\mathrm{PCO}_{2}=$ & $4.83 \times 10^{-5}$ & $\$ / g$ & \\
\hline & Energy $(\$)=$ & $(\text { reed prod })^{*}($ tran & tion coeffic & \\
\hline & Energy $(\$)=$ & $\left(1.50 \times 10^{11} \mathrm{~g}\right)^{*}(0$ & $32 / 44^{*}(4.83$ & \\
\hline & $=$ & $3.38 \times 10^{6}$ & $\$$ & \\
\hline & $\mathrm{UEV}=$ & $1.21 \times 10^{13}$ & $\mathrm{sej} / \$$ & King [32] \\
\hline \multirow{10}{*}{11} & Soil fixation & & & \\
\hline & Area $=$ & $5.78 \times 10^{8}$ & $\mathrm{~m}^{2}$ & \\
\hline & $\begin{array}{l}\text { Wetland soil erosion modulus } \\
=\end{array}$ & 0 & $g^{*} m-2 a-1$ & \\
\hline & Lawn soil erosion modulus $=$ & 200 & $g^{* m}-2 a-1$ & \\
\hline & Volume weight of soil $=$ & 1.03 & $\mathrm{~g} / \mathrm{cm}^{3}$ & \\
\hline & Soil price $=$ & 9.13 & $\$ / \mathrm{m}^{3}$ & \\
\hline & Energy $(g)=$ & $\begin{array}{l}\text { (area)*(Lawn soil } \\
\text { of soil * Soil price }\end{array}$ & n modulus & dulus)/Volume weight \\
\hline & Energy $(J)=$ & $\left(5.78 \times 10^{8} \mathrm{~m}^{2}\right)^{*}($ & $\left.g^{*} m-2 a-1\right)$ & $\left.13 \$ / \mathrm{m}^{3}\right)$ \\
\hline & $=$ & $1.02 \times 10^{6}$ & \$/year & \\
\hline & $\mathrm{UEV}=$ & $1.21 \times 10^{13}$ & $\mathrm{sej} / \mathrm{g}$ & King [32] \\
\hline \multirow{14}{*}{12} & Organic carbon & & & \\
\hline & Area $=$ & $5.78 \times 10^{8}$ & $\mathrm{~m}^{2}$ & \\
\hline & Deposition rate of soil $=$ & $1.93 \times 10^{-3}$ & $\mathrm{~m} /$ year & Wang [34] \\
\hline & bulk density of soil $=$ & $1.02 \times 10^{6}$ & $\mathrm{~g} / \mathrm{m}^{3}$ & \\
\hline & content of organic carbon $=$ & 25.9 & $\mathrm{~g} / \mathrm{kg}$ & LUO [35] \\
\hline & standard calorific of carbon $=$ & 8 & $\mathrm{kcal} / \mathrm{g}$ & \\
\hline & conversion coefficient $=$ & 4186 & $\mathrm{~J} / \mathrm{kcal}$ & \\
\hline & Energy $(\mathrm{J})=$ & $\begin{array}{l}(\text { area })^{*}(\text { depositio } \\
\text { carbon })^{*} \text { conversi }\end{array}$ & $\begin{array}{l}\text { of soil })^{*}(\mathrm{bu} \\
\text { fficient) }\end{array}$ & d calorific of \\
\hline & Energy $(\mathrm{J})=$ & $\begin{array}{l}\left(5.78 \times 10^{8} \mathrm{~m}^{2}\right)^{*}( \\
(8 \mathrm{kcal} / \mathrm{g})^{*}(4186 \mathrm{~J}\end{array}$ & $\mathrm{n} /$ year $)^{*}(1$ & g) $/ 1000^{*}$ \\
\hline & $=$ & $9.86 \times 10^{14}$ & $\mathrm{~J} /$ year & \\
\hline & $\mathrm{UEV}=$ & 4700 & $\mathrm{sej} / \mathrm{J}$ & Odum [18] \\
\hline & $\mathrm{TN}$ & & & \\
\hline & Area $=$ & $5.78 \times 10^{8}$ & $\mathrm{~m}^{2}$ & \\
\hline & Deposition rate of soil $=$ & $1.93 \times 10^{-3}$ & $\mathrm{~m} /$ year & Wang [34] \\
\hline
\end{tabular}


Table 2. Cont.

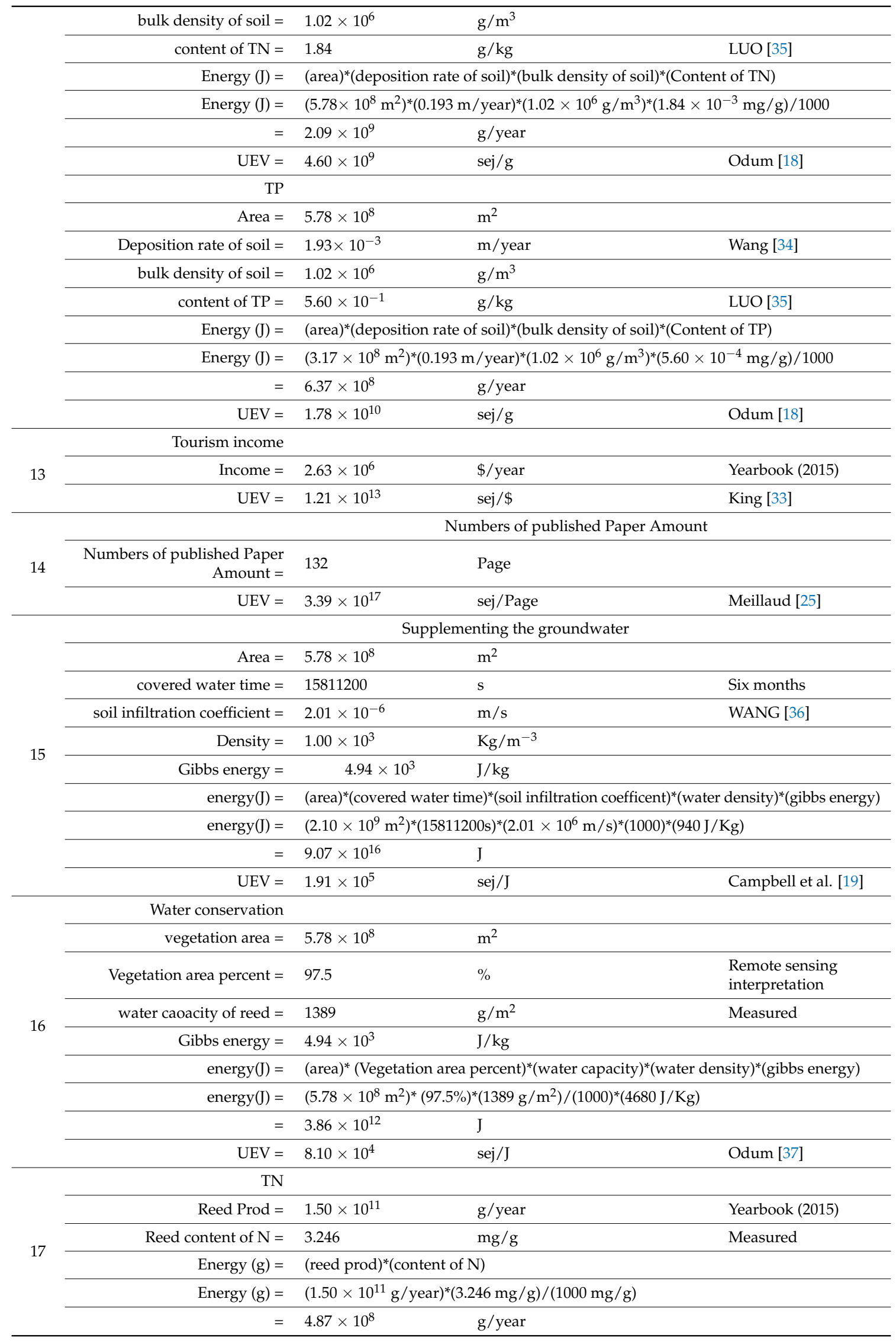


Table 2. Cont

\begin{tabular}{|c|c|c|c|c|}
\hline & $\mathrm{UEV}=$ & $4.60 \times 10^{9}$ & $\mathrm{sej} / \mathrm{g}$ & Odum [18] \\
\hline \multicolumn{5}{|c|}{$\mathrm{TP}$} \\
\hline & Reed Prod $=$ & $1.50 \times 10^{11}$ & g/year & Yearbook (2015) \\
\hline & Reed content of $\mathrm{P}=$ & 1.661 & $\mathrm{mg} / \mathrm{g}$ & Measured \\
\hline & Energy $(g)=$ & \multicolumn{3}{|c|}{$(\text { reed prod })^{*}($ content of $\mathrm{N})$} \\
\hline & Energy $(g)=$ & \multicolumn{3}{|c|}{$\left(1.50 \times 10^{11} \mathrm{~g} / \text { year }\right)^{*}(1.661 \mathrm{mg} / \mathrm{g}) /(1000 \mathrm{mg} / \mathrm{g})$} \\
\hline & $=$ & $2.49 \times 10^{8}$ & g/year & \\
\hline & $\mathrm{UEV}=$ & $1.78 \times 10^{10}$ & sej/g & Odum [18] \\
\hline \multicolumn{5}{|c|}{ Bird } \\
\hline \multirow{10}{*}{18} & Protected bird species $=$ & 8 & species & \\
\hline & $\mathrm{UEV}=$ & $5.17 \times 10^{22}$ & sej/species & Brown et al. [38] \\
\hline & Normal bird & & & \\
\hline & migratory birds extracted $=$ & $1 \times 10^{5}$ & bird/year & Yearbook (2015) \\
\hline & Avg. mass $=$ & $1.30 \times 10^{3}$ & $\mathrm{~g} / \mathrm{bird}$ & \\
\hline & energy content $=$ & $8.83 \times 10^{3}$ & $\mathrm{~J} / \mathrm{g}$ & \\
\hline & $\operatorname{energy}(J)=$ & \multicolumn{3}{|c|}{ (migratory bird)*(Avg. mass)*(energy content)(dry weight propotion) } \\
\hline & $\operatorname{energy}(J)=$ & \multicolumn{3}{|c|}{$(\mathrm{bird} / \text { year })^{*}\left(1.30 \times 10^{3} \mathrm{~g} / \mathrm{bird}\right)^{*}\left(8.83 \times 10^{3} \mathrm{~J} / \mathrm{g}\right)(0.2)$} \\
\hline & $=$ & $2.30 \times 10^{11}$ & J/year & \\
\hline & $\mathrm{UEV}=$ & $1.01 \times 10^{5}$ & $\mathrm{sej} / \mathrm{J}$ & Brown et al. [38] \\
\hline
\end{tabular}

\subsection{Analysis and Evaluation of Wetland Ecosystem Service Value}

The value of the Liaohe estuarine wetland ecosystem service was analyzed in terms of ultimate and intermediate service values, and the results were listed in Table 3. For ultimate service value, the value of adjusting the atmosphere was $28.45 \%$ of the ultimate service value of the Liaohe estuarine ecosystem, and flood diversion and storage $24.75 \%$, which suggests that the Liaohe estuarine wetland ecosystem plays a positive role on regional gas regulation and flood control. The values of gas regulation, and flood diversion and storage were more than half of the total value, illustrating they are the main service value of the Liaohe estuarine wetland ecosystem. The value of material production occupied $9.50 \%$ of the ultimate service value, in which the value of aquatic products (crabs, shrimp, freshwater fish, sea cucumber) was higher, and reed value was lower. The crab product is one of the main economic sources, which can cause an obvious effect on the income of local residents. The value of scientific research and education was $13.12 \%$ and leisure-entertainment value $9.33 \%$, which indicates that the Liaohe estuarine wetland has an important regional status. The values of water-quality purification was $3.72 \%$ of the total value, which is less for this wetland. For intermediate service values, the value of biodiversity was $95.98 \%$ of the total, the value of supplementing groundwater $4.02 \%$, the value of nutrient recycling $0.34 \%$, and the value of water conservation $0.00004 \%$, which illustrates that the main intermediate value of the Liaohe estuarine wetland is maintaining biodiversity. Comparing the values of ultimate and intermediate services of the Liaohe estuarine wetland in 2015, there is a difference of $\$ 1650.1$ million. This suggests energy loss occurring during the process of providing human-value services in the wetland. 
Table 3. Proportion of service value of the Liaohe estuarine wetland ecosystem.

\begin{tabular}{|c|c|c|c|c|c|}
\hline \multicolumn{3}{|c|}{ Ultimate Service } & \multicolumn{3}{|c|}{ Intermediate Service } \\
\hline Service Index & $\begin{array}{c}\text { Emergy } \\
\text { Currency } \\
\text { Value/ } \times 106 \$\end{array}$ & $\begin{array}{c}\text { Proportion } \\
(\%)\end{array}$ & Service Index & $\begin{array}{c}\text { Emergy } \\
\text { Currency } \\
\text { Value } / \times 10^{6} \$\end{array}$ & $\begin{array}{c}\text { Proportion } \\
\text { (\%) }\end{array}$ \\
\hline Material production & 2.68 & 9.50 & Supplementing groundwater & 1431.63 & 4.02 \\
\hline Flood diversion and storage & 6.98 & 24.75 & Water conservation & 0.03 & 0.00007 \\
\hline Water quality purification & 1.05 & 3.72 & Nutrient recycling & 0.55 & 0.0015 \\
\hline Leisure entertainment & 2.63 & 9.33 & & & \\
\hline Scientific research and education & 3.70 & 13.12 & & & \\
\hline Total & 28.20 & 100.00 & & & \\
\hline
\end{tabular}

\section{Discussion}

In this study, our findings adequately emphasize that the significance of the Liaohe estuarine wetland ecosystem is in maintaining biodiversity. We identified that its value was $\$ 34,181.82$ million, accounting for $95.98 \%$ of the total intermediate value $(\$ 35,614.03$ million), this being around 1263 times more than the ultimate value ( $\$ 28.20$ million) of the Liaohe estuarine wetland ecosystem, which explains why a lot of the server values were dissipated during the service process.

In other studies, quantifying the service value of a wetland ecosystem usually adopts econometric methods, but the quantifying results remove the richness of estuarine wetland ecosystem [39]. For each econometric method, with both its advantages and disadvantages, the evaluation index and method are also different due to the evaluation objectives and purpose. This causes large differences between evaluation results, leading even to low comparability [40]. In addition, ecosystem evaluation based on classifying the ecosystem services into noninterrelation types can cause double calculation of services owing to their actual relations [17]. In this study, we distinguished between ultimate and intermediate service valuse by defining the inflow and outflow of energy, materials, or services into common units according to the system diagram of the Liaohe estuarine wetland ecosystem, avoiding the double calculation of service values, and achieving comparability between different types of energy and material. Comparing all values of the UEV in this ecosystem, the UEV of bird protection was the maximum $\left(5.17 \times 10^{22}\right)$. Although there are only eight species of protected birds in this wetland ecosystem, its biodiversity value was also the maximum. This finding illustrates that every protected bird successfully survives in this wetland ecosystem, resulting from a large amount of energy and material in the ecosystem. This is adequate to explain why we especially need to protect these bird species.

This evaluation result based on emergy theory can provide high comparability between different services, especially the intermediate service values of the Liaohe estuarine wetland ecosystem, and can draw more attention to the service process of an ecosystem from decision makers and managers. This evaluation and classification method of ecosystem services in not only suitable for the Liaohe estuarine wetland ecosystem, but can be applied to other ecosystems, such as forest and grassland ecosystems.

\section{Conclusions}

This study evaluated the ecosystem service value of the Liaohe estuarine wetland by adopting the emergy analysis method. The ecosystem service values of the Liaohe estuarine wetland were classified as either ultimate or intermediate service values based on emergy flow, which avoided double counting in ecosystem service values, and increased the accuracy of the evaluation result. We concluded that the ultimate service value of this wetland ecosystem was mainly embodied in flood diversion and storage, and atmospheric adjustment services, and the intermediate service value was in maintaining biodiversity. This study can more explicitly explain the ecosystem service value of the Liaohe estuarine wetland for managers, promoting protection policies and actions in total storage capacity, reed areas, and bird populations in this wetland ecosystem. 
We also noticed limitations of this emergy analysis method. First, data acquisition was difficult in the region due to a lack of an ecosystem-monitoring system. It is easy for deviations from the actual results to appear with our estimation method to obtain the data. Second, the selection of the emergy value units (transformity and specific emergy) directly affected the credibility of the evaluation result. In this paper, the emergy value unit was mainly based on the research results of Odum and Brown, which are mostly conclusions on a global scale. Although the local emergy unit value was difficult to obtain, it was more adaptable for emergy calculation in the local region. Finally, the continuous evaluation of some ecosystems should be implemented based on continuous monitoring of data to recognize ecosystem-service trends, which can assist decision makers in developing better ecological-protection planning and measurement of management.

Based on this study case, the calculation method of ultimate and intermediate service values of a wetland ecosystem based on emergy theory can be applied to other wetland systems. The calculation results would also provide a more appropriate reference to decision makers, and draw more attention to the service process of wetland systems, promoting the simultaneous sustainable development of human society and the natural environment.

Author Contributions: L.L. and F.S. conceived and designed the experiments; L.L. performed the experiments; L.L. and F.S. equally contributed to this paper; L.L. and H.L. analyzed the data; L.L., H.L., and F.S. wrote the paper; and M.T.B. and T.W. reviewed the paper.

Funding: This research was funded by the National Natural Science Foundation of China (No. 31670711, 31570706), the National Key Research and Development Program of China (No. 2016YFC0500408), and the National Natural Science Foundation of Liaoning, China (No. 201602660).

Acknowledgments: We thank the wetland management center of Panjin city, Liaoning Province, China and the wetland administration of Liaohe bureau for providing the support of our field survey and data.

Conflicts of Interest: The authors declare no conflict of interest.

\section{References}

1. Mark, S.; Tom, S.; Stijn, T.; Matthew, L.K.; Claudia, W.; Daniel, L.; Chris, J.M.; Mark, D.P.; Ruth, R.; Athanasios, T.V.; et al. Future response of global coastal wetlands to sea-level rise. Nature 2018, 561, 231-247.

2. Costanza, R.; de Groot, R.; Braat, L.; Kubiszewski, I.; Fioramonti, L.; Sutton, P.; Farber, S.; Grasso, M. Twenty years of ecosystem services: How far have we come and how far do we still need to go? Ecosyst. Serv. 2017, 28, 1-16. [CrossRef]

3. Costanza, R.; D'arge, R.; Groot, R.D.; Farber, S.; Grasso, M.; Hannon, B.; Limburg, K.; Naeem, S.; O'Neill, R.V.; Paruelo, J.; et al. The value of the world's ecosystem services and natural capital. Nature 1997, 387, 253-260. [CrossRef]

4. Groot, R.S.D.; Wilson, M.A.; Boumans, R.M.J. A typology for the classification, description and valuation of ecosystem functions, goods and services. Ecol. Econ. 2002, 41, 393-408. [CrossRef]

5. Sarukhan, J.; Whyte, A.; Hassan, R.; Scholes, R.; Ash, N.; Carpenter, S.T. Millenium Ecosystem Assessment: Ecosystems and Human Well-Being; Synthesis; Island Press: Washington, DC, USA, 2005.

6. Sutton, P.C.; Costanza, R. Global estimates of market and non-market values derived from nighttime satellite imagery, land cover, and ecosystem service valuation. Ecol. Econ. 2002, 41, 509-527. [CrossRef]

7. Fan, X.; Jiang, C.; Zhang, Y. Evaluation of Ecological Footprint of Sustainable Development and Ecological Security in Jiangsu Province. J. HoHai Univ. (Nat. Sci.) 2005, 3, 255-259.

8. Jenkins, W.A.; Murray, B.C.; Kramer, R.A.; Faulkner, S.P. Valuing ecosystem services from wetlands restoration in the mississippi alluvial valley. Ecol. Econ. 2010, 69, 1051-1061. [CrossRef]

9. Grossmann, M. Impacts of boating trip limitations on the recreational value of the Spreewald wetland: A pooled revealed/contingent behaviour application of the travel cost method. J. Environ. Plan. Manag. 2011, 54, 211-226. [CrossRef]

10. Lannas, K.S.M.; Turpie, J.K. Valuing the provisioning services of wetlands: Contrasting a rural wetland in Lesotho with a peri-urban wetland in South Africa. Ecol. Soc. 2009, 14, 544. [CrossRef] 
11. Zhang, X.; Lu, X. Multiple criteria evaluation of ecosystem services for the ruoergai plateau marshes in southwest china. Ecol. Econ. 2010, 69, 1463-1470. [CrossRef]

12. Nelson, E.; Mendoza, G.; Regetz, J.; Stephen, P.; Heather, T.; DRichard, C.; Kai MA, C.; Gretchen, C.D.; Joshua, G.; Peter, M.K.; et al. Modeling multiple ecosystem services, biodiversity conservation, commodity production, and tradeoffs at landscape scales. Front. Ecol. Environ. 2009, 7, 4-11. [CrossRef]

13. Larocque, G.R.; Bhatti, J.S.; Ascough, J.C.; Liu, J.; Luckai, N.; Mailly, D.; Archambault, L.; Gordon, A.M. An analytical framework to assist decision makers in the use of forest ecosystem model predictions. Environ. Model. Softw. 2011, 26, 280-288. [CrossRef]

14. Boyd, J.; Banzhaf, S. What are ecosystem services? The need for standardized environmental accounting units. Ecol. Econ. 2007, 63, 616-626. [CrossRef]

15. Fisher, B.; Turner, K.; Zylstra, M.; Brouwer, R.; Groot, R.D.; Farber, S.; Ferraro, P.; Green, R.; Hadley, D.; Harlow, J.; et al. Ecosystem services and economic theory: Integration for policy-relevant research. Ecol. Appl. 2008, 18, 2050-2067. [CrossRef] [PubMed]

16. Barnard, R.; Wolff, R.C. Bringing ecosystem services into the real world: An operational framework for assessing the economic consequences of losing wild nature. Environ. Resour. Econ. 2011, 48, 161-175.

17. Li, k.; Cui, L.; Li, W.; Kang, X.; Zhang, Y. Removing double counting in wetland ecosystem services valuation based on emergy algebra. Chin. J. Ecol. 2016, 35, 1108-1116.

18. Odum, H.T. Environmental Accounting: Emergy and Environmental Decision Making; John Wiley \& Sons Inc.: Hoboken, NJ, USA, 1996; pp. 1-380.

19. Campbell, E.T.; Brown, M.T. Environmental accounting of natural capital and ecosystem services for the US National Forest System. Environ. Dev. Sustain. 2012, 14, 691-724. [CrossRef]

20. Lu, H.F.; Tan, Y.W.; Zhang, W.S.; Qiao, Y.C.; Campbell, D.E.; Zhou, L.; Ren, H. Integrated emergy and economic evaluation of lotus-root production systems on reclaimed wetlands surrounding the Pearl River Estuary, China. J. Clean. Prod. 2017, 158, 367-379. [CrossRef] [PubMed]

21. Brown, M.; Ulgiati, S. Emergy-based indices and ratios to evaluate sustainability: Monitoring economies and technology toward environmentally sound innovation. Ecol. Eng. 1997, 9, 51-69. [CrossRef]

22. Odum, H.; Brown, M.; Brandt-Williams, S.L. Handbook of Emergy Evaluation; University of Florida: Gainesville, FL, USA, 2000.

23. Bastianoni, S.; Campbell, D.; Susani, L.; Tiezzi, E. The solar transformity of oil and petroleum natural gas. Ecol. Model. 2005, 186, 212-220. [CrossRef]

24. NEAD. The National Environmental Accounting Database. Ph.D. Dissertation, University of Florida, Gainesville, FL, USA, 2016.

25. Tilley, D. Emergy Basis of Forest Systems; Center for Environmental Policy, University of Florida: Gainesville, FL, USA, 1999.

26. Brown, M.T. A picture is worth a thousand words: Energy systems language and simulation. Ecol. Model. 2004, 178, 83-100. [CrossRef]

27. Meillaud, F.; Brown, M.T. Evaluation of a building using the emergy method. Sol. Energy 2005, 79, $204-212$. [CrossRef]

28. Li, L.; Hui, S.; Song, H.; Su, F. Evaluation of the services provided by the Shuangtai estuary wetland in Panjin based on emergy theory. China Environ. Sci. 2013, 33, 1454-1458.

29. Chen, X.; Su, F.; Lu, X.; Zhou, X.; Wang, T. Application of Fuzzy Mathematics in Water Quality Evaluation of Shuangtaihekou Wetland. Water Sav. Irrig. 2011, 5, 45-56.

30. Lu, X.; Wang, T.; Ma, X.; Zhou, L.; Zhang, Y. Research for Environmental Impact Assessment and Restoration of Shuangtai Estuary Wetland in Panjin City. Res. Soil Water Conserv. 2011, 2, 133-138.

31. Liu, J. Comparisons of ecosystem services among three conversionsystems in Yancheng National Nature Reserve. Ecol. Eng. 2009, 35, 609-629. [CrossRef]

32. King, D.M.D. Emergy Accounting of the Resource Basis of Nations, Human Well-Being and International Debt. Master's Thesis, University of Florida, Gainesville, FL, USA, 2006.

33. Vilbiss, C.D.D.; Brown, M.T. New method to compute the emergy of crustal minerals. Ecol. Model. 2015, 315, 108-115. [CrossRef]

34. Wang, X.; Siyuan, Y.; Han, Z. The sedimentary environment evolution and biogenic silica records of the Liaohe Estuary since 33 ka BP. Geol. China 2015, 42, 1092-1102. 
35. Luo, X.; Zhang, S.; Dun, M. Spatial Distribution and Seasonal Dynamics Characteristics of Carbon, Nitrogen and Phosphorus in the Liaohe Estuary Wetlands. Period. Ocean Univ. China 2010, 12, 97-104.

36. Wang, Z.; Zhao, Q.; Hao, X.; Siyuan, Y.; University Q. Study on permeability coefficient of surface sediments in Liaohe Delta Wetland. Shangdong Land Resour. 2013, Z1, 84-86.

37. Odum, H.T.; Brown, M.T.; Brandt-Williams, S. Handbook of Emergy Evaluation; Folio\#2, Emergy of Global Processes. Florida, Center for Environmental Policy; University of Florida: Gainesville, FL, USA.

38. Brown, M.T.; Cohen, M.; Bardi, E.; Ingwerson, W.W. Species diversity in the Florida everglades: A systems approach to calculating biodiversity. Aquat. Sci. 2006, 68, 254-277. [CrossRef]

39. Boutwell, J.L.; Westra, J.V. Benefit transfer: A review of methodologies and challenges. Resources 2013, 2, 517-527. [CrossRef]

40. Trégarot, E.; Failler, P.; Maréchal, J.P. Evaluation of coastal and marine ecosystem services of Mayotte: Indirect use values of coral reefs and associated ecosystems. Int. J. Biodivers. Sci. Ecosyst. Serv. Manag. 2017, 13, 19-34. [CrossRef]

(C) 2018 by the authors. Licensee MDPI, Basel, Switzerland. This article is an open access article distributed under the terms and conditions of the Creative Commons Attribution (CC BY) license (http://creativecommons.org/licenses/by/4.0/). 